\title{
Becoming gardeners \\ Seeding local curricula with the ACRL Framework for Information Literacy
}

$\mathbf{T}$ he ACRL Framework for Information Literacy for Higher Education ${ }^{1}$ is a tool through which instruction librarians are invited to develop and revise information literacy student learning outcomes, design tailored instructional approaches to teaching those outcomes, and assess student learning in the context of those outcomes. The methods involved in using the Framework to accomplish these tasks are not new, as Megan Oakleaf outlined for the profession while the Framework was still being developed. ${ }^{2}$ But the Framework itself is new, although librarians have been working with the document since the first draft became available in 2014. ${ }^{3}$ The Framework's formal adoption by the ACRL Board of Directors in January 2016 positions it as a newly available source of conceptual structure and inspiration for our work within the longer cycles of local curricular and program review. The concepts and approaches espoused in the Framework are like a packet of seeds waiting to be planted on each of our local campuses, according to the specific needs of our students, faculty, and curricula. The resulting flowers are shared, but their arrangement on each campus will differ.

To this end, I believe the most pressing need during the next three-to-five years is for practitioners to further develop and articulate the Framework locally at various curricular levels. This process involves experimenting with arranging the seeds provided by the
Framework within and across campus curricula as a gardener would strategically plant seeds in fertile soil. Our gardening tools are the creative and strategic articulation, instruction, and assessment of information literacy student learning outcomes in a variety of learning domains (including cognitive, behavioral, and dispositional), scopes (including classroom, course, program, and institution), and developmental levels (from foundational to graduate level). In this article I will offer strategies and a model from my own campus for mapping the Framework to existing curricular programs, articulating outcomes linked to the frames at different levels in the curriculum, and using this generative analysis to identify opportunities for information literacy interventions at all levels, tending the Framework's seeds so they grow into a locally grown harvest.

\section{Our seeds and soil: The Framework and campus curricula}

Putting the Framework in conversation with campus curricula is just one approach to using the Framework locally to meaningfully impact students' learning and development of information literacy. Trudi E. Jacobson

Donna Witek is associate professor and public services librarian at the University of Scranton Weinberg Memorial Library, email: donna.witek@scranton.edu

() 2016 Donna Witek 
and Craig Gibson propose this approach when they say, "To develop a larger program architecture using the Framework, information literacy librarians will need to conduct systematic curriculum analyses and design curriculum maps to identify those courses and programs that are the most natural 'fit' or homes for the six Frames." ${ }^{4}$ They go on to remind us that "charting 'learning pathways' vertically [through curricula] will vary widely from institution to institution," supporting the idea that the arrangement of the Framework's seeds—its concepts and approaches—within and across curricula will look different from campus to campus.

At my own institution, the University of Scranton, a private, Catholic, Jesuit liberal arts university with around 5,000 FTE, the general education (GE) curriculum was undergoing review and rearticulation at the same time the Framework was being developed by ACRL. Through representation on the faculty senate and collaborative partnerships with faculty across campus, the University of Scranton Weinberg Memorial Library was invited to the table and was able to advocate for information literacy within the rearticulated curriculum, adopted by the faculty senate in May 2014. ${ }^{6}$ Of particular note is the higher-level GE goal that explicitly names information literacy: "Students will demonstrate technological and information literacy." "The inclusion of information literacy in such a high-profile position situates librarians as partners in teaching this core curriculum to our students.

A central component in the rearticulated GE curriculum to both to the GE program as a whole and to information literacy specifically is the Eloquentia Perfecta component. Latin for "perfect eloquence," Eloquentia Perfecta is a Jesuit pedagogical goal that "aims to develop students' abilities to generate topics of inquiry; to gather, evaluate, and disseminate information and ideas; and to communicate in varied modes within appropriate contexts and disciplines, so that they are empowered to excel as professionals and citizens to serve more fully the common good." ${ }^{8}$ This GE component houses the skills-based courses required of every student at the university: writing, oral communication, digital technology, and on the foundational level, first-year seminar. Based on the mission of Eloquentia Perfecta and the courses included in its requirements, it was clear to us in the library that this part of the curriculum was ripe for information literacy intervention. But curricular development is never linear, and the relationship between Eloquentia Perfecta, the Framework, and the Weinberg Memorial Library's information literacy program is both rich and complex, emerging iteratively over time.

In 2014, as the rearticulated GE curriculum was working its way through the faculty senate, librarians worked to identify and develop five information literacy program student learning outcomes, in order to engage in a formal outcomes-based assessment plan and review cycle for information literacy on our campus. Once the Framework was filed by the ACRL Board of Directors in February 2015, we sought to revise our outcomes to more closely align with the Framework's concepts and in response to what we learned through our first year of assessment, adding a sixth outcome as we did so. Our updated outcomes map to the University of Scranton's Institutional Learning Outcomes ${ }^{9}$ as well as to the Framework.

The remaining questions for us in the library are: In what ways does the Eloquentia Perfecta component of the GE curriculum complement, support, and enhance our newly revised information literacy program outcomes? And could that relationship be mutually beneficial?

\section{The gardener's tools: Developmental outcomes}

The Eloquentia Perfecta component of the GE curriculum was designed at two levels: foundational (Level I), occurring in 100-level courses that address first-year outcomes in writing, oral communication, digital technology, and first-year seminar; and rhetorical (Level II), occurring in courses at the 200-level and above that address advanced outcomes in 
writing, oral communication, and digital technology. This bifurcation balances the need for students to develop foundational knowledge, skills, and dispositions that can be transferred across contexts, with the understanding that deep learning requires they be situated in particular contexts, such as students' majors and future professions.

The two curricular levels of Eloquentia Perfecta are a concrete example of what I am calling in this article developmental outcomes. Developmental outcomes consider the end goal as a matrix of knowledge, skills, and dispositions related to a particular area of study, and sequence their learning so that outcomes are tailored to the developmental level of the student in relation to their program of study. This means that outcomes embedded in upper levels of curricula necessarily build on outcomes targeted and developed at lower levels. It makes sense that advanced learning builds on the learning that came before it, but here I argue that this should be built explicitly into our information literacy programs and curricula, and that the Framework can be a valuable starting point for this process.

One example of developmental outcomes in the information literacy context can be found in the Research Skills Development (RSD) framework developed by John Willison and Kerry O'Regan, ${ }^{10}$ an Australian framework that I believe is compatible with and complements the ACRL Framework. The RSD framework "enables the explicit, incremental and coherent development of students' and academics' research skills," where the developmental levels are framed around "students' autonomy when researching." 11

Another example of developmental outcomes situated on a campus and using the Framework as a blueprint is Northern Kentucky University's Steely Library Information Literacy Learning Outcomes. ${ }^{12}$ The Steely Library outcomes are divided first by level ("Foundational," "Advanced (Discipline-Specific)," and "Graduate"), and then by learning domain ("I understand," "I can," and "I value"). Within these cat- egories specific outcomes are then mapped to each frame. ${ }^{13}$

As Northern Kentucky University's Steely Library illustrates, many campuses already structure their information literacy program outcomes incrementally and according to varying levels within the curriculum, levels which, in well-designed curricula, correspond to an increase in students' autonomy when researching. However, the Framework's proposed knowledge practices and dispositions are not articulated at different levels-nor should they be, since they are not composed as concrete, measurable student learning outcomes. The knowledge practices and dispositions in the Framework are not meant to be comprehensive nor exhaustive. The Framework invites librarians to rigorously develop these lists further, as the Steely Library information literacy librarians have done. In the absence of an already developmentally articulated set of information literacy program outcomes, local curricular programs that share goals and objectives with information literacy, like the Eloquentia Perfecta component of the GE curriculum at my university, are a good place to begin the work of articulating the Framework in outcomes-based language, at multiple levels within local curricula.

The foundational level of Eloquentia Perfecta (Level I) was approved for implementation in May 2014, which means the library has been working with these foundational outcomes for more than two years now. The articulation of our information literacy program outcomes took place in conversation with both the Framework and the foundational level of Eloquentia Perfecta on our campus. Mapping the Eloquentia Perfecta foundational outcomes in the four first-year designations to our information literacy program outcomes was a first step we could take to see how information literacy manifests on this foundational level in our local curriculum. ${ }^{14}$

Because we have already mapped our information literacy program outcomes to the Framework, these two maps can be linked 
for further analysis of how the six frames manifest in our campus' Eloquentia Perfecta foundational outcomes. Classroom-level outcomes can then be developed by individual librarians in the context of these mapped program-level outcomes and the Framework's concepts, strengthening the architecture of our individual and collective information literacy instruction.

The Eloquentia Perfecta rhetorical outcomes (Level II) were approved by the faculty senate in May 2016 for implementation in 2017. Since they are not yet applied to specific upper-level courses across the curriculum, the library is only beginning to work with these outcomes. To the extent that these outcomes relate to information literacy, there is an opportunity for the library to collaborate and liaise with disciplinary departments as they situate these outcomes in their courses, rearticulate them within their fields of study, and develop appropriate pedagogy and assessments. In preparation for these partnerships, mapping the Eloquentia Perfecta rhetorical outcomes to the Framework illustrates the aspects of information literacy that manifest in this upper rhetorical level of the curriculum.

This information is useful to the library as we consider how best to target the frames in students' later years of study.

\section{Our harvest: Integration and collaboration}

The process of seeding local curricula with the Framework is long, iterative, and generative. Making connections between the Framework, information literacy program outcomes, and curricular outcomes developed and adopted by faculty in departments across our university is a powerful strategy through which information literacy can be embedded "vertically" through curricula, as Jacobson and Gibson describe. ${ }^{15}$ Potential impacts of this work include opportunities to reach out to departments for collaboration; to create shared assessment projects across campus constituencies; and to develop intentional, targeted information literacy learning experiences for students.
Further analyses of our local curricula will need to take place as the Eloquentia Perfecta course designations on both the foundational and rhetorical levels are applied to more courses housed in specific disciplinary departments. These analyses will provide valuable information to our information literacy liaison librarians as they reach out to their departments in a targeted, strategic manner. Understanding the Framework as a lens through which to identify information literacy in already existing local curricula, as well as a tool through which to sow information literacy where its explicit integration appears to be thin, positions librarians as partners with faculty in other departments in growing information literacy on our campuses and in our students.

\section{Notes}

1. "Framework for Information Literacy for Higher Education," ACRL, accessed August 8, 2016, www.ala.org/acrl/standards /ilframework.

2. Megan Oakleaf, "A Roadmap for Assessing Student Learning Using the New Framework for Information Literacy for Higher Education," Journal of Academic Librarianship 40, no. 5 (2014): 510-14. Pre-print openly available at http:// meganoakleaf.info/framework.pdf (accessed August 8, 2016).

3. See the "Framework Spotlight on Scholarship" post series for published examples as far back as 2014 of librarians using the Framework: http://acrl.ala.org /framework/?cat=17 (accessed August 8, 2016).

4. Trudi E. Jacobson and Craig Gibson, "First Thoughts on Implementing the Framework for Information Literacy," Communications in Information Literacy 9, no. 2 (2015): 104, www.comminfolit.org/index. php?journal $=$ cil $\&$ page $=$ article $\&$ op $=$ view $\&$ pa th $\% 5 B \% 5 \mathrm{D}=\mathrm{v} 9 \mathrm{i} 2 \mathrm{p} 102 \&$ path $\% 5 \mathrm{~B} \% 5 \mathrm{D}=213$.

5. Ibid.

6. "The General Education Program at the University of Scranton," accessed August 8, 2016, www.scranton.edu 
/academics/provost/PDFs/Assessment Integrated $\% 20 \mathrm{GE} \% 20$ Document $\% 20$ incl $\% 20$ EP $\% 209 \% 20$ Nov $\% 202015 \% 20$ ed $\% 20$ 31\%20May\%202016.pdf.

7. Ibid., 2.

8. Quoted from the "Eloquentia Perfecta Level I: Foundational" document, approved by the University of Scranton faculty senate in May 2014.

9. "Information Literacy Assessment," The University of Scranton: A Jesuit University, accessed August 8, 2016, www.scranton.edu/ academics/wml/infolit/assessment.shtml.

10. John Willison and Kerry O'Regan, "Commonly known, commonly not known, totally unknown: A framework for students becoming researchers," Higher Education Research E Development 26, no. 4 (2007): 393-409. Preprint openly available at www. adelaide.edu.au/rsd/evidence/related -articles/RSD_article_web.doc (accessed August 8, 2016).

11. "Research Skill Development for curriculum design and assessment," University of Adelaide, accessed August 8, 2016, www. adelaide.edu.au/rsd/. The "Detailed RSD" defines the levels of students' autonomy when researching, as well as the "Facets of Research" within which research-related outcomes are developed, www.adelaide.edu.au/rsd/ framework/RSD_27_March16.pdf (accessed August 8, 2016).

12. Jane Hammons, listserv post "[acrlframe] Framework Inspired Learning Outcomes," ALA listserv: acrlframe, May 24, 2016, accessed August 8, 2016, http:// lists.ala.org/sympa/arc/acrlframe/2016-05 /msg00060.html. The Northern Kentucky University Steely Library Information Literacy Outcomes can be accessed at https://docs. google.com/document/d/1KnPAvzqNDVUB B0eveF3kMAU6udRQV0v8PTEEZ0_51OU/ edit?usp=sharing (accessed August 8, 2016).

13. Ibid.

14. View this article online for tables mapping the Framework, Information Literacy Program Student Learning Outcomes, and Eloquentia Perfecta outcomes.

15. Jacobson and Gibson, "First Thoughts," 104. r

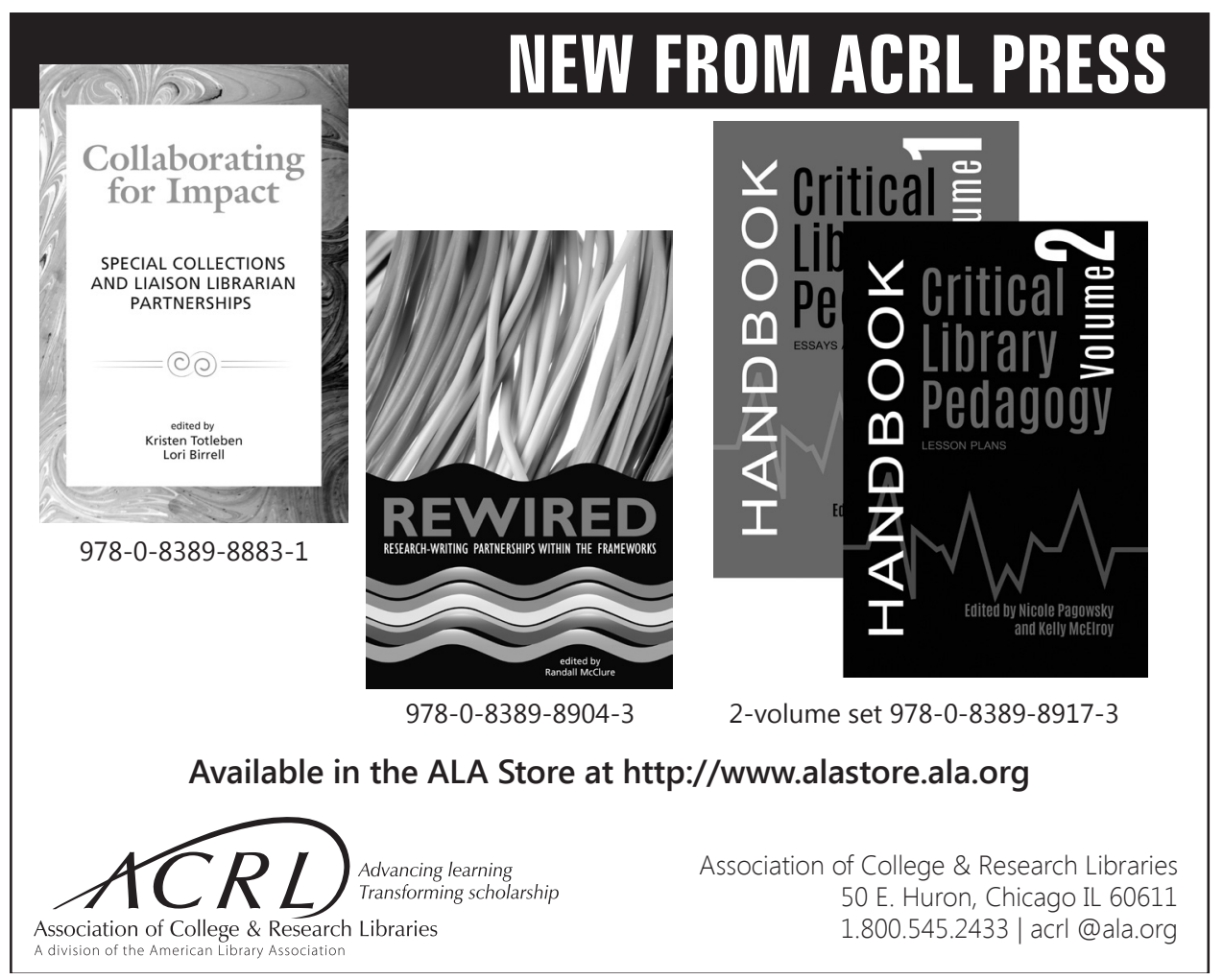

